\title{
Biometry in plant systematics of European and Mediterranean gymnosperms, a review
}

\author{
Katarzyna Marcysiak*
}

\section{Article info}

Received: 12 Mar. 2021

Revision received: 6 Aug. 2021

Accepted: 6 Aug. 2021

Published: 31 Dec. 2021

\section{Associate Editor}

Monika Dering

\begin{abstract}
The morphological features of plants, which were the basis of taxonomic solutions in the past, are now sometimes less appreciated due to the intensive development of genetic methods. The present review looks at the results of the research on the taxonomy of plants carried out by the team led by A. Boratyński. The team characterized the taxonomic and geographical differentiation of some species of the genera Abies, Juniperus, Pinus, Cupressus, Cedrus, as well as several others. Many of these studies were carried out in the Mediterranean area due to its importance for biodiversity. The results allowed unravelling taxonomic ambiguities, emphasizing the importance of geographic barriers in shaping variability, e.g., the Strait of Gibraltar or the Aegean Sea, and highlighting the role of mountain ranges as refuges, e.g., the Taurus and Anti-Taurus Mountains. All of the results obtained with biometrics were confirmed by genetic methods by different authors. Detailed research allowed the publication of a new name, Juniperus thurifera subsp. africana (Maire) Romo \& Boratyński, stat. nov., and restoration of species status for the dubious taxon Juniperus canariensis. The review shows that relying on the research of a large number of correctly sampled populations and correctly selected differentiated characteristics of plants allows the generation of reliable results.
\end{abstract}

Key words: Abies, Cedrus, Cupressus, Juniperus, morphological characters, Pinus, plant taxonomy

\section{Introduction}

The authors of one of the popular books on biometry, Sokal and Rohlf (2003), refer to this field as 'the application of statistical methods to the solution of biological problems'. Undoubtedly, the systematics of plants constantly provides many problems to be solved. This branch of science, one of the goals of which is to create a common language for researchers, is evolving dynamically owing to the development of new research methods, like AFLP analysis, DNA fingerprinting, cpDNA and ITS sequencing. Taxonomic research using these methods often leads to taxonomic revisions, changing the previously known classifications, i.e., in the case of Malpighiales (Wurdack \& Davis 2009), Pinaceae (Ran et al. 2018), and many others. In the past, plant morphology was the basis for classification, as other traits had not yet been observed and studied (Stace 1993). Recently, their role has been decreasing because of rapid development of molecular biology and modern methods of DNA analysis, treated as more reliable and more sensitive, especially for reflecting

Uniwersytet Kazimierza Wielkiego, Wydział Nauk Biologicznych, Al. Ossolińskich 12, 85-093 Bydgoszcz, Poland ORCID: 0000-0001-6162-6232

* Corresponding author e-mail: marc@ukw.edu.pl the intra-specific diversity (Levin 2001; Culham 2006). Still, despite cases of basing species diagnoses only on DNA characters (Renner 2016), it is hard to imagine identifying plants based on DNA as a common practice.

In this review, a selection of works based on plant biometrics, the results of which have been useful for taxonomic research of some Gymnosperm species, was discussed. The review was based on publications made by a group of researchers gathered around Professor Adam Boratyński. This review aimed to show that reliable research methods developed over the years by his team have brought significant results that were important the modern world of genetic analyses and constituted their necessary supplementation, as well as helping in taxonomic decisions.

\section{Systematic structure of closely related taxa}

Determining the systematic position of taxa is especially important for complex species, which occupy large or separated ranges, and show great variability. Dwarf mountain pine Pinus mugo Turra sensu Christensen (1987) is one such case. This taxon is treated as the complex species with P. mugo s.str. occurring in Eastern and Central 
European, and P. uncinata, occurring in Western Europe. Both species grow in the mountains, forming their own vast communities, and although their acreage has decreased as a result of human activity, they play a key environmental role (Amaral Franco 1986; Bogunić et al. 2011; Švajda et al. 2011). Systematics of these taxa were more complex due to the possible hybridizing between them in the area where their ranges overlap. Sometimes the closely related P. uliginosa (Amaral Franco 1986; Businský 1999) has been included into $P$. mugo s.lat. The research conducted on the basis of a large amount of material collected from the entire range of the taxa mentioned and with the use of morphological features of both the vegetative (needles) and generative (cones) organs allowedto reaching strong conclusions. Results obtained did not justify including P. ucinata as a Western-European subspecies into the complex species $P$. mugo, juxtaposed with the typical dwarf mountain pine covering the mountains of Central and Eastern Europe (Boratyńska \& Boratyński 2007; Marcysiak \& Boratyński 2007; Boratyńska et al. 2015a). The systematic position of bog pine, P. uliginosa, was more difficult to interpret due to the high inter-population variability and not fully consistent results obtained for different sets of traits, nevertheless the combination of vegetative and generative characteristics allowed distinguishing it from closely related P. mugo, P.uncinata and $P$. sylvestris (Boratyńska et al. 2011; Boratyńska et al. 2015a). Problems with delimiting a clear systematic structure based on morphological features could be explained by the relatively young history of speciation of the analyzed taxa (Wachowiak et al. 2011). Recent genetic studies confirmed the results obtained on the basis of morphological features, including the variability of the P. uliginosa populations, due to probable hybridization with related species (Łabiszak et al. 2019).

Problems with determining the systematic position often concern taxa of small ranges, e.g., of a relict nature, separated from the most closely related taxa by various types of geographic barriers. In a few cases, such taxa are designated either as separate species or as collective species comprising several subspecies or varieties. Determining the taxonomic level of differentiation (interspecies or intraspecific) is difficult and requires a lot of research into multiple traits. The genus Abies (firs) in the Central European and Mediterranean part of the range consists of 11 taxa (EUFORGEN 2021), and systematic position of some of them is constantly discussed (Linares 2011; Litkowiec et al. 2021). Several Mediterranean fir species have distributions confined to very limited areas, and Abies alba is the only species with a widespread European range (Dering et al. 2014). A. pinsapo s.lat. grows only in the most western part of the Mediterranean on both sides of the Strait of Gibraltar (Farjon 2010). This taxon includes three varieties: var. pinsapo (growing in three areas of the Baetic Mountains in southern Spain), var. maroccana (Trab.) Ceballos et Martín Bol. (a few stands in the Rif Mountains) and var. tazaotana (Côzar ex Villar) Pourtet (one population in the Tazaot Mountains) (Liu 1971; Farjon 2010). However, more authors considered these taxa as separate species: A. pinsapo,
A. maroccana and A. tazaotana (e.g., Terrab et al. 2007), while others believe there are only two species here (Maire \& Weiller 1952), or one species with two varieties (Farjon 2010). The examination of 33 morphological and anatomical traits confirmed the recognition of the two species: A pinsapo and A. marrocana, and the lack of evidence for distinguishing $A$. tazaotana (Sękiewicz et al. 2013). This result was consistent with previous genetic findings (Terrab et al. 2007) and stressed the role of the Strait of Gibraltar as a significant barrier. Another fir species, A. cilicica (Antoine \& Kotschy) Carrière, is found mainly in the Taurus and Anti-Taurus Mountains in Turkey, and in Syria and Lebanon (Linares 2011). The aridification of climate and the consequent spatial isolation of populations of this species in the mentioned massifs led to differentiation of the species into two subspecies: eastern A. cilicica subsp. cilicica and western A. cilicica subsp. isaurica Cullen \& Coode. This differentiation was supported by analyses of nuclear microsatellites (Sękiewicz et al. 2015). Morphometric studies using a specially developed set of features allowed the determination of the exact morphological differences between these subspecies and showed further geographic differentiation of A. cilicica subsp. cilicica (Boratyńska et al. 2015b). Only 27 trees grow in the natural stand of $A$. nebrodensis in the Madonie Mountains of Sicily (Conte et al. 2004), thus it is one of the most endangered conifer species in the world [IUCN: CR (D)]. The taxonomic distinctiveness of this species was verified and confirmed with biometric analyses of morphological and anatomical needle traits (Jasińska et. al. 2017). A summary work based on a large amount of material from 38 fir populations of species from Europe and West Asia confirmed the correctness of the previous findings (Litkowiec et al. 2021). The genetic and morphological results were consistent, which allows for the morphological identification of fir species in the future, as well as the examination of fossils. The results of the studies carried out with these two methods together allowed for the following conclusions: A. alba was genetically distant from other taxa and internally geographically differentiated; A. pinsapo, A. marrocana, A. nebrodensis, A. cephalonica and $A$. cilicica were also taxonomically different from other taxa, and A.cilicica was divided into two subspecies; A. equitrojani, A. bornmuelleriana and $A$. nordmanniana were closely related and should be treated as a subspecies of $A$. nordmanniana (Litkowiec et al. 2021).

The Mediterranean cedars (Cedrus) are another taxa with ranges that have shrunk due to the cooling of the climate towards the end of the Tertiary, and the widespread use of its precious wood contributed significantly to the current threat to the species (Postigo-Mijarra et al. 2010). The progressive isolation of individual sites has led to differentiation and speciation, but the taxonomy of the distinguished units is controversial (Jasińska et al. 2013). Cedrus libani is a commonly recognized species, and two other species, C. brevifolia (Hook. f.) Henry and C. atlantica (Endl.) G.Manetti ex Carriére, are sometimes considered subspecies of $C$. libani. The examination of these taxa based on the morphological and anatomical features 
of needles indicated that they provide valuable tools in discrimination of the taxa, and the detected differentiation confirms the distinction of three separate species of cedar (Jasińska et al. 2013). Importantly, the differences among the populations from the West Taurus, the Anti-Taurus and the Lebanon Mountainswere found, similarly as in the case of Abies cilicica (Boratyńska et al. 2015b).

There are three species of Mediterranean cypress trees (Cupressus), and their natural ranges have shrunk due to the drying and cooling of the climate, as in the case of the previously discussed species. Their systematics is also controversial. Different authors distinguished either three separate species: C. sempervirens, C. atlantica Gaussen and C. dupreziana, or one-two species and a different number of subspecies (Sękiewicz et al. 2016). Thanks to the study of the populations of $C$. sempervirens and C. atlantica from the entire range of their occurrence, their accurate morphological characteristics were obtained for the first time and their taxonomic distinctiveness was confirmed. Cupressus sempervirens was found to be further differentiated, which was related to the different regions of origin of populations (Sękiewicz et al. 2016). It should be noted that differentiation between the populations from the Taurus Mountains and Lebanon was discovered, similar to the species discussed above (Jasińska et al. 2013; Boratyńska et al. 2015b).

Junipers are keystone species in arid and semi-arid areas of the Mediterranean basin, therefore studies of the variability and interrelationships between species of this genus are important, also for the protection of gene pools of these species. The study of three such species: J. thurifera, J. excelsa subsp. excelsa and J. foetidissima, proved morphological vicinity of the first two species and their difference from $J$. foetidissima, despite the sympatry of ranges of $J$. excelsa and $J$. foetidissima, which might suggest their close relation (Marcysiak et al. 2007). These results confirmed the hypothesis about a common ancestor of these three species and their early divergence resulting from the cooling of the climate at the end of the Tertiary (Barbero et al. 1994; Jiménez et al. 2003).

Taxonomy of the Mediterranean prickly juniper $J$. oxycedrus is not yet definitively resolved, and a group of related taxa comprises $J$. navicularis, J. macrocarpa and J. deltoides (cryptic species), J. brevifolia (Seub.) Antoine, J. cedrus, J. maderensis (Menezes) R. P. Adams and two subspecies: J. oxycedrus subsp. oxycedrus and $J$. oxycedrus subsp. badia (H.Gay) (Adams 2011). The thorough morphological examination of these taxa, combined with nuclear microsatellite markers analyses, helped to disentangle complicated relationships. The analyses indicated the distinctiveness of $J$. macrocarpa, J. navicularis and $J$. deltoides, and the lack of justification for distinguishing subspecies of $J$. oxycedrus, which should be treated as a homogeneous species (Boratyński et al. 2014).

\section{Intra-specific differentiation: new taxa}

Longstanding research on the intra-species diversity of Spanish juniper, J. thurifera, gave important results. This juniper grows in the mountains in the western part of the Mediterranean zone, in Europe and Africa; hence, its stands are strongly isolated. The significant morphological differences between parts of its range distant from one another were proved, and the level of differences between the European and African populations allowed for treating them as belonging to separate taxa at the level of a subspecies: subsp. thurifera and subsp. africana (Mazur et al. 2005; Romo \& Boratyński 2007; Boratyński et al. 2013). These results were in accordance with the findings of earlier biochemical and genetic analyses (Jiménez et al. 2003; Terrab et al. 2008). As the African subspecies did not have a valid nomenclatural status, the new subspecific name was published: Juniperus thurifera subsp. africana (Maire) Romo \& Boratyński, stat. nov. (Romo \& Boratyński 2007).

A similar problem was discussed in research concerning Phoenicean juniper $J$. phoenicea, mainly occupying coasts of the Mediterranean Sea and growing inland mostly in the Iberian Peninsula and Northwest Africa (Jalas \& Suominen 1973; Farjon 2005). Based on the morphological diversification of this juniper, the existence of two subspecies, subsp. phoenicea and subsp. turbinata., was definite (Mazur et al. 2003, 2010, 2016), although these taxa were treated sometimes as varietes or separate species. Confirmation of the significant division of $J$. phoenicea into two taxa using isoenzymes allowed treating them as separate species: J. phoenicea s.lat. and $J$. turbinata. The addition of research material from the Canary Islands to the analyses confirmed the outstanding distinctiveness of the species $J$. canariensis, proposed earlier by some researchers (Mazur et al. 2018). It was proposed to distinguish a taxon from the Canary Islands as a separate species, previously published by Mathou \& Guyot (1942), as Juniperus canariensis (Romo et al. 2019).

\section{Geographical structure of morphological differentiation}

Some plant species, in spite of occupying wide ranges, do not show any evidence of internal taxonomic differentiation. Scots pine, Pinus sylvestris, with its extensive Eurasian range shows predominantly clonal variability, and the inter-specific taxa proposed by various authors are rarely generally accepted (Boratyński 1993). The greatest variability occurs in populations at the southern and western extremities of the range, where the species faces unfavorable climate conditions. Knowledge of the intra-species diversity in these parts of the range, especially if they have been long-term isolated from the rest of the range, is essential for the protection of the species' entire diversity, preservation of its gene pool and for identifying endangered populations. The study of phenotypic differentiation of relic P. sylvestris in southern Europe and southwestern Asia showed the highest differentiation between the Iberian and Anatolian populations and generally the geographical structure of variability (Jasińska et al. 2014). Distinguishing P. sylvestris subsp. hamata, which was supposed to occur in Crimea and Anatolia (Molotkov \& Patlaj 1991), was not justified. 
Juniperus drupacea has a less extensive range, but it is divided between Europe (the Peloponnese) and Asia (the Taurus and Lebanon Mountains) (Boratyński \& Browicz 1982; Browicz 1982). The biometric investigations, in accordance with genetic analysis, indicated a high level of morphological divergence between the European and Asian populations of the species, with further differentiation between the populations from the Taurus and Lebanon Mountains (Sobierajska et al. 2016). These results confirmed the general trend of decreasing genetic diversity noted in the eastern to western Mediterranean regions (Fady \& Conord 2010; Conord et al. 2012).

The taxonomic problems mentioned in the previous section were also analyzed in the bio-geographical context. Discussing the reasons for geographic differentiation of plant variability led to conclusions concerning the relations of this differentiation with the history of species and populations. The analysis of the Pinus mugo complex, in addition to taxonomic conclusions, also provided information on the geographical differentiation of the taxon and the role of isolation in shaping the variability. The largest distance between marginal populations in the west-east direction caused large differences between the Pyrenean and Carpathian populations (Boratyńska et al. 2015a). Disparities between the East and West Carpathians were also fund, what is consistent with the biography of the massif (Ronikier 2011).

Research on Mediterranean species, especially junipers, has made it possible to learn about the biogeographical features of this region and the plants of arid environments. The geographical structure of morphological differentiation of Mediterranean juniper species resulted from migration of these plants and the divergence of populations isolated by different periods. The findings concerning the taxonomies of $J$. thurifera, J. excelsa and $J$. foetidissima confirmed hypotheses suggesting two routes of migration of this species: eastward and westward, from the northern Alpine foreland, which led to the breakdown of the range (Marcysiak et al. 2007). The differentiation of $J$. thurifera into two subspecies was closely related to the biogeography of the species and could be treated as an example of allopatric speciation (Mazur et al. 2005; Boratyński et al. 2013). The breakdown of the species can be interpreted as an effect of migration of the species or its ancestor caused by the Miocene cooling of the climate. The Gibraltar Straight appeared to be the most important barrier in shaping the differentiation of the taxon (Boratyński et al. 2013).

The analyses of another juniper, $J$. excelsa subsp. excelsa, proved a much smaller intra-specific differentiation and only weak geographical structure (Mazur et al. 2004; Douaihy et al. 2012). However, the most differentiated populations of this taxon corresponded to old, isolated populations in the high altitudes of Lebanon (Douaihy et al. 2012). Similar interrelations were found in the case of $J$. oxycedrus. Samples of J. oxycedrus subsp. macrocarpa from Italy did not show big differentiation (Klimko et al. 2004), whereas the analysis of a large amount of material of $J$. oxycedrus subsp. oxycedrus from the Mediterranean area proved morphological differences between eastern and western parts of the range (Klimko et al. 2007). Analyses results managed to link the variability of J. oxycedrus subsp. oxycedrus with the migration history. This taxon has a very wide range comprising the whole of the Mediterranean area and populations from its eastern and western parts differ from one other. This proves the origin of these two range parts from different Pleistocene refugia, located also in the eastern and western parts of the area, where the populations might have been in isolation even since the Tertiary (Klimko et al. 2007).

In the case of the aggregate Juniperus phoenicea, the situation is more complex. Although the main habitat difference between $J$. phoenicea s.str and $J$. turbinata was choice of different ecological niches, with the former prefering the meso- or supramediterranean belt of western Spain, France and northwestern Italy, and the latter prefering the thermomediterranean belt (Mazur et al. 2016), the geographical structure also was evident here. Recognizing J. canarienis as a separate species confirmed the role of the Macaronesian islands as refugia of the ancestral lineages, as well as the importance of isolation in shaping differentiation (Mazur et al. 2018). Further geographical differentiation of J. turbinata was found with the Gibraltar Strait and Aegean Sea acting as the bariers, which confirmed the phenomenon found for other species, e.g., J. thurifera (Boratyński et al. 2013) and J. drupacea (Sobierajska et al. 2016), respectively.

\section{Review of the biometrical methods}

In the works discussed, the biometric characteristics of both generative organs, i.e., in the case of Gymnosperms cones and seeds, and vegetative ones, i.e., leaves and possibly fragments of shoots, were analyzed. In both groups of characteristics, features were measured or counted, and synthetic features were usually also calculated on their basis. The qualitative features sometimes were also used, but as they were difficult to apply in calculations, they were often transformed, for example, into the percentage of occurrences of a given feature state. The selection of features was based on previous research and characteristics tested for other species were also used and sometimes new features were developed.

The features of the cones differed depending on the cone structure. They were analyzed for the genus Juniperus, Cupressus and Pinus. In each case, the length and diameter of the cone, as well as the length and width of the seeds, were measured. These traits were usually unimodal and they characterized and differentiated the taxa well. In particular, the length of the cone and the length and/or width of the seed have proven useful for distinguishing between populations, intra-specific taxa and closely related species in the cases of $J$. phoenicea aggr. (Mazur et al. 2003, 2010, 2016, 2018), J. excelsa (Douaihy et al. 2012), J. oxycedrus (Klimko et al. 2007; Boratyński et al. 2014), genus Cupressus (Sękiewicz et al. 2016) and genus Pinus (cone characteristics only) (Marcysiak 2005; Marcysiak \& Boratyński 2007). The limitations in the use of these features were their mutual correlations, as well as correlations with other features 
measuring the size of cones, and sometimes also with the synthetic characters, i.e., the correlation of cone length with ratio of cone length/diameter. The number of rows of cone scales, the number of cone scales and the number of seeds were discontinuous features used in research on junipers. Sometimes they required transformation to be subjected to statistical analyses. The number of scales rows was significant in the differentiation of the taxa of the J. phoenicea complex (Mazur et al. 2018), while the number of seeds clearly differentiated individual juniper species (Marcysiak et al. 2007. The number of cone scales was less applicable, because the method of its calculation seemed ambiguous due to the presence of very small, falling off scales at the base of the cone, although this trait turned out to be useful in the case of $J$. drupacea (Sobierajska et al. 2016). In the case of pine species, the number of cone scales was counted and their apophyses were also measured. These features were unimodal and distinguished different species well, although the dimensions of the apophyses had several correlations with other features of the cones, especially strong with their width.

Due to the structure of leaves and shoots of the genus Cupressus and junipers from the Sabina section, i.e., J. phoenicea, J. excelsa and $J$. thurifera, only two features of vegetative organs were examined: the number of needles per $5 \mathrm{~mm}$ apical section of ultimate lateral branchlet and the thickness of the ultimate lateral branchlet with leaves. The values of both features usually had a normal distribution. The features were not correlated with each other and weakly, if at all, correlated with the features of cones. The branchlet thickness was especially useful in differentiating taxa. The studies of most characteristics of needles in the Pinaceae family (Pinus, Abies and Cedrus genera) were carried out on preserved material, under a microscope. The characteristics recorded included the dimensions of the needles, the number of stomata rows and number of stomata, as well as several additional anatomical features. Two descriptive features of sclerenchyma cells were also taken into account, and their states were expressed as a percentage of occurrences, which allowed including these features in statistical analyses (Boratyńska \& Boratyński 2007). Despite this, the distribution of the values of the latter features was often biased and their coefficient of variation was very high (Boratyńska et al. 2015a). Nevertheless, the characteristics of the sclerenchyma cells proved useful in the taxonomic study of pines, especially for distinguishing between related two-needle pine species. However, the characteristics of epidermal cells and the distance between the vascular bundles were more important, as well as the length of the needles, although this feature was correlated with other needle traits (Boratyńska et al. 2014, 2015a). The number of stomata, counted on the fragment of both the abaxial and the adaxial side of the needle, was of less importance in the study of pines, but turned out to

Table 1. Number of analyzed populations, individuals and characters in studies of taxa cited.

\begin{tabular}{|c|c|c|c|c|}
\hline \multirow{2}{*}{ Taxon } & \multirow{2}{*}{ Sources } & \multicolumn{3}{|c|}{ Total number analyzed } \\
\hline & & populations & individuals & characters \\
\hline Abies (C. Europe, Mediterranean) & $\begin{array}{l}\text { Sękiewicz et al. (2013) } \\
\text { Boratyńska et al. (2015b) } \\
\text { Sękiewicz et al. (2015) } \\
\text { Jasińska et al. (2017) } \\
\text { Litkowiec et al. (2021) }\end{array}$ & 38 & 1218 & 33 \\
\hline Cedrus libani, C. brevifolia, C. atlantica & Jasińska et al. (2013) & 9 & 259 & 25 \\
\hline Cupressus sempervirens, C. atlantica & Sękiewicz et al. $(2016,2018)$ & 18 & 446 & 17 \\
\hline Juniperus drupacea & Sobierajska et al. (2016) & 12 & 1100 & 17 \\
\hline Juniperus excelsa subsp. excelsa & $\begin{array}{l}\text { Mazur et al. (2004) } \\
\text { Douaihy et al. (2012) }\end{array}$ & 14 & 394 & 17 \\
\hline Juniperus oxycedrus & $\begin{array}{l}\text { Klimko et al. (2004) } \\
\text { Klimko et al. (2007) } \\
\text { Boratyński et al. (2014) }\end{array}$ & 41 & 1100 & 16 \\
\hline $\begin{array}{l}\text { Juniperus phoenicea s.lat. (including } \\
\text { J. turbinata, J. canariensis) }\end{array}$ & $\begin{array}{l}\text { Mazur et al. (2003) } \\
\text { Mazur et al. (2010) } \\
\text { Mazur et al. (2016) } \\
\text { Mazur et al. (2018) } \\
\text { Romo et al. (2019) }\end{array}$ & 41 & 1156 & 15 \\
\hline Juniperus thurifera & $\begin{array}{l}\text { Romo \& Boratyński (2007) } \\
\text { Boratyński et al. (2013) }\end{array}$ & 17 & 441 & 12 \\
\hline $\begin{array}{l}\text { Pinus mugo s.lat. (including } P \text {. uncinata, } \\
\text { P. uliginosa) }\end{array}$ & $\begin{array}{l}\text { Marcysiak et al. (2003) } \\
\text { Boratyńska (2004) } \\
\text { Boratyńska et al. (2005) } \\
\text { Marcysiak (2005) } \\
\text { Marcysiak et al. (2007) } \\
\text { Boratyńska et al. (2011) } \\
\text { Boratyńska et al. (2014) } \\
\text { Boratyńska et al. (2015a) }\end{array}$ & 24 & 766 & 24 \\
\hline Pinus sylvestris & Jasińska et al. (2014) & 32 & 951 & 39 \\
\hline
\end{tabular}


be important in taxonomic analyses of cedars and firs (Jasińska et al. 2013; Litkowiec et al. 2021).

It is obvious that the choice of morphological or anatomical features to be examined should always be matched to the analyzed taxa. Characteristics used in the analysis of related species or species with a similar organ structure can sometimes be used, although this requires pilot studies.

\section{Reliability of biometric analyses}

The main criticism of morphological characters is connected with their dependence on changing environmental factors, such as precipitation, temperature, and insolation (Huber \& Wiggerman 1997; Noda et al. 2004; Marchand et al. 2006; Baquedano et al. 2008; Fletcher et al. 2010). The proposed solution is to use synthetic characters, describing the shape of the plant structures rather than their size, that are regarded as much more stable (Kremer et al. 2002; Marcysiak 2012). On the other hand, the variability of the size of plants and plant organs is valuable information. An effective method of avoiding the effects of the environmental impact on the examined objects is a careful selection of populations and individuals for study. In the studies analyzed above, a lot of attention was paid to the selection of individuals (e.g., Boratyńska et al. 2014: 'Material ... was collected from ... individuals ... at distances of about $30-40 \mathrm{~m}$ from each other to avoid possible duplicate sampling from the same genet'), as well as of collection of plant organs from an individual (e.g., Mazur et al. 2010: 'The samples ... were gathered ... from the southern parts of individuals, at a height of about 1.0-2.5 $\mathrm{m}$ above ground level.'), thanks to which similar environmental conditions of the collected material were maintained. The reliability and objectivity of morphological research is also ensured by the application of the principles of numerical taxonomy, i.e., primarily the use of a large number of different characters in research, treated as equivalent, and basing the research on a large number of units analysed, which were usually individuals (e.i. trees) of taxa (Sneath \& Sokal 1973). These requirements were fulfilled by the studies cited above (Table 1).

\section{Conclusions}

The cited examples of taxonomic studies show that properly selected morphological features are very important in systematic decisions. In combination with molecular or genetic features, they can be the basis for a reliable description of species variability, as well as for taxonomic diagnoses. In the discussed studies, the genetic and morphological results were consistent, which justifies the use of biometrics in future analyses. In particular, the following traits were useful in taxonomic studies: a set of needle characters for the taxonomy of genus Abies and Cedrus, characters of cones, seeds and shoots for the taxonomy of Cupressus sp., Juniperus excelsa, J. phoenicea and $J$. thurifera, features of cones, seeds and needles for $J$. drupacea and $J$. oxycedrus, and characters of cones and needles for the taxonomy of Pinus sp.

\section{References}

Adams, R. P. 2011. Junipers of the World: the genus Juniperus. 3rd ed., pp. 436. Trafford Publishing Co, Bloomington, IN.

Amaral Franco, J. 1986. Pinus L. In: Castroviejo, S., Lainz, M., Lopez Gonzalez, G., Montserrat, P., Muñoz Garmendia, F., Paiva, J. \& Villar, L. (eds), Flora Iberica. Vol. 1, pp. 168-174. Madrid, Real Jardin Botanico C.S.I.C.

Baquedano, F. J., Valladares, F. \& Castillo, F. J. 2008. Phenotypic plasticity blurs ecotypic divergence in the response of Quercus coccifera and Pinus halepensis to water stress. European Journal of Forest Research 127: 495-506. https://doi.org/10.1007/s10342-008-0232-8

Barbero, M., Lebreton, Ph. \& Quézel, P. 1994. Sur les affinités biosystématiques et phytoécologiques de Juniperus thurifera L. et de Juniperus excelsa Bieb. Ecologia Mediterranea 20(3/4): 21-37.

Bogunić, F., Siljak-Yakovlev, S., Muratović, E., Pustahija, F. \& Medjedović, S. 2011. Molecular cytogenetics and flow cytometry reveal conserved genome organization in Pinus mugo and P. uncinata. Annals of Forest Science 68: 179-197. https://doi.org/10.1007/ s13595-011-0019-9

Boratyńska, K. 2004. Relacje taksonomiczne między sosnami z kompleksu Pinus mugo (Pinaceae) na podstawie cech igieł. Fragmenta Floristica et Geobotanica Polonica 11(2): 235-255.

Boratyńska, K. \& Boratyński, A. 2007. Taxonomic differences among closely related pines Pinus sylvestris, $P$. mugo, $P$. uncinata, $P$. rotundata and $P$. uliginosa as revealed in needle sclerenchyma cells. Flora 202: 555-569. https://doi.org/10.1016/j.flora.2006.11.004

Boratyńska K., Marcysiak K. \& Boratynski A. 2005. Pinus mugo (Pinaceae) in the Abruzzi Mountains: high morphological variation in isolated populations. Botanical Journal of the Linnean Society 147: 309-316.

Boratyńska K., Jasińska A. K., Marcysiak K. \& Sobierajska K. 2011. Pinus uliginosa from Czarne Bagno peat-bog (Sudetes) compared morphologically to related Pinus species. Dendrobiology 65: 17-28.

Boratyńska, K., Dzialuk, A., Lewandowski, A., Marcysiak, K., Jasińska, A. K., Sobierajska, K., Tomaszewski, D., Burczyk, J. \& Boratyński, A. 2014. Geographic distribution of quantitative traits variation and genetic variability in natural populations of Pinus mugo in Central Europe. Dendrobiology 72: 65-84.

Boratyńska, K., Jasińska, A. K. \& Boratyński, A. 2015a. Taxonomic and geographic differentiation of Pinus mugo complex on the needle characteristics. Systematics and Biodiversity 13(6): 581-595. https:// doi.org/10.1080/14772000.2015.1058300

Boratyńska, K., Sękiewicz, K., Jasińska, A. K., Tomaszewski, D., Iszkuło, G., Ok, T., Bou, Dagher-Kharrat M. \& Boratyński, A. 2015b. Effect of geographic range discontinuity on taxonomic differentiation of Abies cilicica. Acta Societatis Botanicorum Poloniae 84: 419-430. https://doi.org/10.5586/asbp.2015.037

Boratyński, A. 1993. Systematyka i geograficzne rozmieszczenie. In: Białobok, S., Boratyński, A. \& Bugała, W. (eds) Biologia sosny zwyczajnej, pp: 45-69. Polska Akademia Nauk, Instytut Dendrologii. Sorus Poznań-Kórnik.

Boratyński, A. \& Browicz, K. 1982. Juniperus drupacea in Greece. Arboretum Kórnickie 27: 3-16.

Boratyński, A., Boratyńska, K., Mazur, M. \& Marcysiak, K. 2007. Seed involucre variation in Carpinus betulus (Corylaceae) in Poland. Acta Botanica Cracoviensia Series Botanica 49/1: 103-111.

Boratyński, A., Jasińska, A. K., Marcysiak, K., Mazur, M., Romo, A., Boratyńska, K., Sobierajska, K. \& Iszkuło, G. 2013. Morphological differentiation supports the genetic pattern of the geographic structure of Juniperus thurifera (Cupressaceae). Plant Systematics and Evolution 299: 773-784. https://doi.org/10.1007/s00606-0130760-7

Boratyński, A., Wachowiak, W., Dering, M., Boratyńska, K., Sękiewicz, K., Sobierajska, K., Jasińska, A. K., Klimko, M., Monsterrat, J., M., Romo, A., Ok, T. \& Didukh, Ya. 2014. The biogeography and genetic relationships of Juniperus oxycedrus and related taxa 
from the Mediterranean and Macaronesian regions. Botanical Journal of the Linnean Society 174: 637-653. https://doi.org/10.1111/ boj. 12147

Browicz, K. 1982. Chorology of trees and shrubs in South-West Asia and adjacent regions. Vol. 1., p. 172. Polish Academy of Science, Institute of Dendrology, Poznań-Kórnik.

Businský, R. 1999. Taxonomická studie agregátu Pinus mugo a jeho hybridnich populace. Acta Pri̊honiciana 68: 123-144.

Christensen, K. I. 1987. Taxonomic revision of the Pinus mugo complex and $P$. $\times$ rhaetica $(P$. mugo $\times$ P. sylvestris $)$. Nordic Journal of Botany 7: 383-408.

Conord, C., Gurevitch, J. \& Fady, B. 2012. Large-scale longitudinal gradients of genetic diversity: a meta-analysis cross six phyla in the Mediterranean basin. Ecology and Evolution 2: 2600-2614. https://doi.org/10.1002/ece3.350

Conte, L., Cotti, C., Schicchi, R., Raimondo, F. M. \& Cristofolini, G. 2004. Detection of ephemeral genetic sub-structure in the narrow endemic Abies nebrodensis (Lojac.) Mattei (Pinaceae) using RAPD markers. Plant Biosystems 138: 279-289. https://doi. org/10.1080/11263500400015515

Culham, A. 2006. Molecular systematics: measuring and monitoring diversity. In: Leadlay, E. \& Jury, S. (eds), Taxonomy and Plant Conservation, pp. 236-254. Cambridge University Press, Cambridge.

Dering, M., Sękiewicz, K., Boratyńska, K., Litkowiec, M., Iszkuło, G., Romo, A. \& Boratyński, A. 2014. Genetic diversity and inter-specific relations of western Mediterranean relic Abies taxa as compared to the Iberian A. alba. Flora 209: 367-374.

Douaihy, B., Sobierajska, K., Jasińska, A. K., Boratyńska, K., Ok, T., Romo, A., Machon, N., Didukh, Y., Bou Dagher-Kharrat, M. \& Boratyński, A. 2012. Morphological versus molecular markers to describe variability in Juniperus excelsa subsp. excelsa $(\mathrm{Cu}$ pressaceae). AoB Plants 2012: pls013. https://doi.org/10.1093/ aobpla/pls013

EUFORGEN 2020 European Forest Genetic Resources Programme. http://www.euforgen.org/species/ [accessed 04 August 2021]

Fady, B. \& Conord, C. 2010. Macroecological patterns of species and genetic diversity in vascular plants of the Mediterranean basin. Diversity and Distribution 16: 53-64. https://doi.org/10.1111/j.14724642.2009.00621.x

Farjon, A. 2005. A monograph of Cupressaceae and Sciadopitys, p. 643. Kew: Royal Botanic Gardens.

Farjon, A. 2010. A handbook of Conifers, pp. 111-113. Brill Academic Publishers, Leiden, Boston.

Fletcher, B. J., Press, M. C., Baxter, R. \& Gareth, K. P. 2010. Arctic landscape: how plant growth and photosynthesis change with abundance at small scales. Oecologia 163: 47-56.

Huber, H. \& Wiggerman, L. 1997. Shade avoidance in the clonal herb Trifolium fragiferum: a field study with experimentally manipulated vegetation height. Plant Ecology 130: 53-62.

Jalas, J. \& Suominen, J. (ed.). 1973. Atlas Florae Europaeae (Vol. 2). Helsinki: The Committee for Mapping the Flora of Europe and Societas Biologica Fennica Vanamo.

Jasińska, A. K., Boratyńska, K., Sobierajska, K., Romo, A., Ok, T., Bou Dhager Kharat, M. \& Boratyński, A. 2013. Relationships among Cedrus libani, C. brevifolia and C. atlantica as revealed by the morphological and anatomical needles characters. Plant Systematic and Evolution 299: 35-48. https://doi.org/10.1007/s00606-012-0700-y

Jasińska, A. K., Boratyńska, K., Dering, M., Sobierajska, K. Ok., T., Romo, A. \& Boratyński, A. 2014. Distance between south-European and south-west Asiatic refugia areas involved morphological differentiation: Pinus sylvestris case study. Plant Systematic and Evolution 300: 1487-1502. https://doi.org/10.1007/s00606-013-0976-6

Jiménez, J. F., Werner, O., Sánchez-Gómez, P., Fernández, S. \& Guerra, J. 2003. Genetic variation and migration pathway of Juniperus thurifera L. (Cupressaceae) in the western Mediterranean region. Israel Journal of Plant Sciences 51: 11-22.
Klimko, M., Boratyńska, K., Boratyński, A. \& Marcysiak, K. 2004. Morphological variation of Juniperus oxycedrus subsp. macrocarpa (Cupressaceae) in three Italian localities. Acta Societatis Botanicorum Poloniae 73: 113-119.

Klimko, M., Boratyńska, K., Montserrat, J. M., Didukh, Y., Romo, A., Gómez, D., Kluza-Wieloch, M., Marcysiak, K. \& Boratyński, A. 2007. Morphological variation of Juniperus oxycedrus subsp. oxycedrus (Cupressaceae) in the Mediterranean region. Flora 202: 133-147.

Kremer, A., Dupouey, J. L., Deans, J. D., Cottrell, J., Csaikl, U., Finkeldey, R., Espinel, S., Jensen, J., Kleinschmit, J., Van Dam, B., Ducousso, A., Forrest,I., Lopez de Heredia, U., Lowe, A. J., Tutkova, M., Munro, R. C., Steinhoff, S. \& Badeau, V. 2002. Leaf morphological differentiation between Quercus robur and Quercus petraea in stable acrosswestern European mixed oak stands. Annals of Forest Science 59: 777-787.

Łabiszak, B., Zaborowska, J. \& Wachowiak, W. 2019. Patterns of $m t$ DNA variation reveal complex evolutionary history of relict and endangered peat bog pine (Pinus uliginosa). AoB Plants 11(2): plz015. https://doi.org/10.1093/aobpla/plz015

Levin, D. A. 2001. 50 years of plant speciation. In: Stuessy, T. F., Hörandl, E. \& Mayer, V. (eds), Plant Systematics: a half-century of progress (1950-2000) and future challenges, pp. 257-280. International Association for Plant Taxonomy, Institute of Botany, University of Vienna, Austria.

Linares, J. C. 2011. Biogeography and evolution of Abies (Pinaceae) in the Mediterranean Basin: the roles of long-term climatic change and glacial refugia. Journal of Biogeography 38: 619-630. https:// doi.org/10.1111/j.1365-2699.2010.02458.x

Litkowiec, M., Sękiewicz, K., Romo, A., Ok, T., Bou Dhager Kharat, M., Jasińska, A. K., Sobierajska, K., Boratyńska, K. \& Boratyński, A. 2021. Biogeography and relationships of the Abies taxa from the mediterranean and central Europe regions as revealed by nuclear DNA markers and needle structural characters. Forest Ecology and Management 479: 118606. https://doi.org/10.1016/j. foreco.2020.118606

Liu, T. 1971. A monograph of the genus Abies, p. 608. Taipei: Department of Forestry College of Agriculture, National Taiwan University.

Maire, R. \& Weiller, M. 1952. Flore del' Afrique du Nord I., p. 158. Paris: Paul Lechevalier.

Marchand, F. L., Kockelbergh, F., van de Vijver, B., Beyens, L. \& Nijs, I. 2006. Are heat and cold resistance of arctic species affected by successive extreme temperature events? New Phytologist 170: 291-300. https://doi.org/10.1111/j.1469-8137.2006.01659.x

Marcysiak, K. 2005. Interpopulational variability of Pinus uncinata Ramond ex DC. in Lam. \& DC. (Pinaceae) cone characters. Dendrobiology 51: 43-51.

Marcysiak, K. 2012. Calculated characters of leaves are independent on environmental conditions in Salix herbacea (Salicaceae) and Betula nana (Betulaceae). Acta Societatis Botanicorum Poloniae 81(3): 153-158. https://doi.org/10.5586/asbp.2012.027

Marcysiak, K. \& Boratyński, A. 2007. Contribution to the taxonomy of Pinus uncinata (Pinaceae) based on cone characters. Plant Systematic and Evolution 264: 57-73. https://doi.org/10.1007/s00606006-0501-2

Marcysiak, K., Boratyńska, K. \& Mazur, M. 2003. Variability of Pinus uliginosa cones from the peat-bog in Weqgliniec. Dendrobiology 49: 43-47.

Marcysiak, K., Mazur, M., Romo, A., Montserrat, J. M., Didukh, Y., Boratyńska, K., Jasińska, A. K., Kosiński, P. \& Boratyński, A. 2007. Numerical taxonomy of Juniperus thurifera, J. excelsa and $J$. foetidissima (Cupressaceae) based on morphological characters. Botanical Journal of the Linnean Society 155: 483-495. https://doi. org/10.1111/j.1095-8339.2007.00730.x

Mathou, Th. \& Guyot, A. P. 1942. Le genévrier des îles Canaries: Juniperus canariensis Guyot. Travaux du Laboratoire Forestier deToulouse T. 1 (fascicule 3), 20: 1-8. 
Mazur, M., Boratyńska, K., Marcysiak, K., Gómez, D., Tomaszewski, D., Didukh, Y. \& Boratyński, A. 2003. Morphological variability of Juniperus phoenicea (Cupressaceae) from three distant localities on Iberian Peninsula. Acta Societatis Botanicorum Poloniae 72 : 71-78

Mazur, M., Boratyńska, K., Marcysiak, K., Didukh, Y., Romo, A., Kosiński, P. \& Boratyński, A. 2004. Low level of inter-populational differentiation in Juniperus excelsa M. Bieb. (Cupressaceae). Dendrobiology 52: 39-46.

Mazur, M., Marcysiak, K., Boratyński, A., Boratyńska, K., Romo, A., Montserrat, J. M. \& Kosiński, P. 2005. Morphological variation of Juniperus thurifera L. (Cupressaceae) from four populations in South-Western Europe. In: Prus-Głowacki, W. \& Pawlaczyk, E. M. (eds) Variability and evolution - new perspectives. Seria Biologia 72: 399-409. Adam Mickiewicz University, Poznań.

Mazur, M., Klajbor, K., Kielich, M., Sowińska, M., Romo, A., Montserrat, J. M. \& Boratyński, A. 2010. Intra-specific differentiation of Juniperus phoenicea in the western Mediterranean region revealed in morphological multivariate analysis. Dendrobiology 63: 21-31.

Mazur, M., Minissale, P., Sciandrello, S. \& Boratyński, A. 2016. Morphological and ecological comparison of populations of Juniperus turbinata Guss. and $J$. phoenicea L. from the Mediterranean region. Plant Biosystems 150: 313-322. https://doi.org/10.1080/11263504. 2014.994579

Mazur, M., Zielińska, M., Boratyńska, K., Romo, A., Salvà-Catarineu, M., Marcysiak, K. \& Boratyński, A. 2018. Taxonomic and geographic differentiation of Juniperus phoenicea agg. based on cone, seed, and needle characteristics, Systematics and Biodiversity 16: 469-483. https://doi.org/10.1080/14772000.2018.1439120

Molotkov, P. I. \& Patlaj, I. N. 1991. Systematic position within the genus Pinus and intraspecific taxonomy. In: Mátyás, C. (ed.) Genetics of Scots pine, pp. 31-40. Akad. Kiadó, Budapest.

Noda, H., Muraoka, H. \& Washitani, I. 2004. Morphological and physiological acclimation responses to contrasting light and water regimes in Primula sieboldii. Ecological Research 19: 331-340. https://doi. org/10.1111/j.1440-1703.2004.00642.x

Postigo-Mijarra, J. M., Morla, C., Barrón, E., Morales-Molino, C. \& García, S. 2010. Patterns of extinction and persistence of Arctotertiary flora in Iberia during the Quaternary. Review of Palaeobotany and Palynology 162: 416-426. https://doi.org/10.1016/j. revpalbo.2010.02.015

Ran, J.-H., Shen, T.-T., Wu, H., Gong, X. \& Wang, X.-Q. 2018. Phylogeny and evolutionary history of Pinaceae updated by transcriptomic analysis. Molecular Phylogenetics and Evolution 129: 106-116. https://doi.org/10.1016/j.ympev.2018.08.011

Renner, S. S. 2016. A Return to Linnaeus's focus on diagnosis, not description: the use of DNA characters in the formal naming of species. Systematic Biology 65(6): 1085-1095. https://doi.org/10.1093/ sysbio/syw032

Romo, A. \& Boratyński, A. 2007. Nomenclatural note on Juniperus thurifera subsp. africana (Cupressaceae). Annales Botanici Fennici 44: $72-75$.

Romo, A., Mazur, M., Salvà-Catarineu, M. \& Boratyński, A. 2019. A re-evaluated taxon: Genetic values and morphological characters support the recognition of the Canary Island juniper of the phoenicea group at a specific level. Phytotaxa 406: 64-70. https://doi. org/10.11646/phytotaxa.406.1.3
Ronikier, M. 2011. Biogeography of high-mountain plants in the Carpathians: An emerging phylogeographical perspective. Taxon 60(2): 373-389. https://doi.org/10.1002/tax.602008

Sękiewicz, K., Sękiewicz, M., Jasińska, A. K., Boratyńska, K., Iszkuło, G., Romo, A. \& Boratyński, A. 2013. Morphological diversity and structure of West Mediterranean Abies species. Plant Biosystems 147: 125-134. https://doi.org/10.1080/11263504.2012.753130

Sękiewicz, K., Dering, M., Sękiewicz, M., Boratyńska, K., Iszkuło, G., Litkowiec, M., Ok, T., Bou Dagher-Kharrat, M. \& Boratyński, A. 2015. Effect of geographic range discontinuity on species differentiation - East-Mediterranean Abies cilicica: a case study. Tree Genetics \& Genomes 11: 10.

Sękiewicz, K., Boratyńska, K., Bou Dhager Kharat, M., Ok, T. \& Boratyński, A. 2016. Taxonomic differentiation of Cupressus sempervirens and $C$. atlantica based on morphometric evidence. Systematics and Biodiversity 14(5): 494-508. https://doi.org/10.1 080/14772000.2016.1171260

Sękiewicz, K., Dering, M., Romo, A., Bou, Dagher-Kharrat m., Boratyńska, K., Ok, T. \& Boratyński, A. 2018. Phylogenetic and biogeographic insights into long-lived Mediterranean Cupressus taxa with a schizo-endemic distribution and Tertiary origin. Botanical Journal of the Linnean Society 188: 190-212.

Sneath, P. H. A. \& Sokal, R. R. 1973. Numerical taxonomy: The principles and practice of numerical classification, p. 573. San Francisco: Freeman.

Sobierajska, K., Boratyńska, K., Jasińska, A., Dering, M., Ok., T., Douaihy, B., Dagher-Kharrat, M. B., Romo, A. \& Boratyński, A. 2016. Effect of The Aegean Sea barrier between Europe and Asia on differentiation in Juniperus drupacea (Cupressaceae). Botanical Journal of the Linnean Society 180: 365-385. https://doi. org/10.1111/boj.12377

Sokal, R. R. \& Rohlf, T. J. 2003. Biometry: The principles and practice of statistics in biological research, Eight printing, p. 887. San Francisco: Freeman W. H. and Comp.

Stace, C. A. 1993. Taksonomia roślin i biosystematyka, p. 340. Wyd. Naukowe PWN, Warszawa.

Švajda, J., Solár, J., Janiga, M. \& Buliak, M. 2011. Dwarf Pine (Pinus mugo) and selected abiotic habitat conditions in the Western Tatra Mountains. Mountain Research and Development 31(3): 220-228. https://doi.org/10.1659/MRD-JOURNAL-D-09-00032.1

Terrab, A., Talavera, S., Arista, M., Paun, O., Stuessy, T. F. \& Tremetsberger, K. 2007. Genetic diversity at chloroplast microsatellites (cpSSRs) and geographic structure in endangered West Mediterranean firs (Abies spp., Pinaceae). Taxon 56: 409-416.

Terrab, A., Schoenswetter, P., Talavera, S., Vela, E. \& Stuessy, T. F. 2008. Range-wide phylogeography of Juniperus thurifera L., a presumptive keystone species of western Mediterranean vegetation during cold stages of the Pleistocene. Molecular Phylogenetics and Evolution 48: 94-102. https://doi.org/10.1016/j.ympev.2008.03.018

Wachowiak, W., Palme, A. E. \& Savolainen, O. 2011. Speciation history of three closely related pines Pinus mugo (T.), P. uliginosa (N.) and P. sylvestris (L.). Molecular Ecology 20: 1729-1743. https:// doi.org/10.1111/j.1365-294X.2011.05037.x

Wurdack, K. J. \& Davis, C. C. 2009. Malpighiales phylogenetics: Gaining ground on one of the most recalcitrant clades in the angiosperm tree of life. American Journal of Botany 96: 1551-1570. https:// doi.org/10.3732/ajb.0800207 